\title{
When and Why do Landlords Retain Property Investments?
}

Gavin Wood, School of Global Studies, Social Sciences and Planning, RMIT University, GPO Box 2476V, Melbourne, Victoria, 3001, Australia.

Rachel Ong, School of Economics and Finance, Curtin University, GPO Box U1987, Perth, Western Australia, 6845, Australia.

\section{Acknowledgement}

The authors would like to thank Clinton McMurray for assistance in the preparation of this paper and three anonymous referees for their constructive comments. The research reported in this paper was funded by grant number 30521 from the Australian Housing and Urban Research Institute (AHURI). This paper uses unit record data from the Household, Income and Labour Dynamics in Australia (HILDA) Survey. The HILDA Project was initiated and is funded by the Australian Government Department of Families, Housing, Community Services and Indigenous Affairs (FaHCSIA) and is managed by the Melbourne Institute of Applied Economic and Social Research (MIAESR). The findings and views reported in this paper, however, are those of the authors and should not be attributed to AHURI, FaHCSIA or the MIAESR.

\footnotetext{
Abstract

This paper examines factors influencing Australian landlords' decisions to retain their rental investments. We apply a variety of statistical techniques to uncover the factors precipitating the exit of landlords from rental housing markets. We find that middle-aged investors are more attached to rental investments than younger investors. However, once retired, there is a sharp increase in the likelihood of exit from rental investments. Our estimates also confirm the importance of financial variables. Leveraged loss-making investors with higher gross rental yields are more inclined to terminate leases. We conclude that fiscal and monetary policy settings play an important role in
} 
shaping rental housing investment decisions, since interest rate and tax parameters are important in determining investors' negative gearing status. These will in turn drive changes in housing supply and affordability in rental markets.

\section{Introduction}

This paper examines factors influencing Australian landlords' decisions to retain their rental investments in the Australian private rental housing tenure. There is a particular significance to this decision because the Australian housing system is largely market driven. Home ownership is the dominant tenure (at $69 \%$ of all households in 2010), while rental housing is typically provided by individual landlords, with social housing a residual tenure that provides housing to only $4 \%$ of Australian households ${ }^{\mathrm{i}}$. In the private rental housing sector there are no rent controls or regulations that guarantee security of tenure, so landlords can give notice and move in to their properties, or sell up at the end of rental leases, or on completion of termination notices. The average Australian tenant's access to affordable rental housing and secure tenancies is then strongly influenced by rental investor decisions about whether to retain rental property investments in wealth portfolios.

In 2006 we estimate that new landlords were responsible for one - in - four private rental lettings; established landlords that acquired their rental properties in previous years were responsible for three in four lettings. The holding period decisions of landlords who acquired their rental investments in previous years will then be critical in shaping short-term changes in the stock of rental housing. These decisions take on an added significance as house prices have spiraled out of the reach of many prospective homeowners, who are turning to the private rental market in increasing numbers to meet their demand for housing services.

But rents have also increased, which is a source of particular concern for low income households as they find it increasingly difficult to access affordable rental housing (Wulff et al., 2009). There are growing fears that private rental housing markets are unable to supply housing in 
the quantity necessary if low income households' housing needs are to be met. An understanding of the key drivers prompting landlord retention decisions can shed insight into the factors precipitating losses of affordable rental housing stock.

The supply decisions of established landlords are important to study for other reasons as well. Of particular interest is the role of tax factors. Numerous countries use tax expenditures to promote the supply of private rental housing. Australia is no exception; investors can subtract operating expenses (other than depreciation) and interest payments on loans from taxable rental income, and are permitted to deduct rental losses from other sources of income. Provided landlords have held their investment property for 12 months or more, capital gains are taxed leniently at $50 \%$ of the investors' marginal income tax rates (MITRs). Rental housing has therefore been an important tax shelter for high and middle income households. There is also evidence to suggest that it has distorted the supply of rental housing (Wood and Tu, 2004), and speculation that investors churn in and out of rental investments to preserve tax shelter benefits (Wood and Ong, 2010).

Landlords' rental investment decisions also have an important bearing on security of tenure given the absence of controls safeguarding the tenancies of private renters in Australia. Secure long term accommodation is an attribute of particular importance to parents whose children's schooling and emotional development can be adversely affected by disruptive moves (Dockery et al., 2010). These considerations prompted governments around the world to introduce security of tenure legislation with a view to protecting the interests of tenants in securing long term accommodation. But in recent years many countries have relaxed their regulations governing tenure security (Haffner et al., 2009), prompting fears that landlord investment decisions will be increasingly driven by private returns that ignore the costs to families when forced moves disrupt community ties.

These fears may be alarmist. Most landlords could plan to hold on to investments in the long 
term as they accumulate wealth to finance retirements. Moreover, landlords with long expected holding periods will prefer tenants with lengthy occupancy intentions because it reduces turnover costs. Indeed there is evidence to suggest that rent discounts accrue to long term tenants (Larsen and Sommervoll, 2009). Even if landlords' holding period intentions do differ, observable signals that help tenants effectively screen landlords could mitigate security of tenure concerns by facilitating successful matching of landlords and tenants. Australia's historical reliance on an unregulated private rental housing tenure as the main source of affordable rental housing is a case study that can shed light on these matching ideas.

The empirical work addresses these research questions using a panel of landlords and their properties. In contrast to previous studies using cross section surveys (Capozza and Seguin, 1996; Crook and Kemp, 2011; Kemp and Rhodes 1997; Ioannides, and Rosenthal, 1994; Kohler and Rossiter, 2005; Seelig et al. 2009; Shroder, 2001; Wood and Kemp, 2003), our data source allows comparison of landlords' property investment portfolios at different points in time. It therefore has the novel feature of being able to analyse decisions over the retention of property investments and the factors shaping these decisions. The modelling exercises reported below investigate the role of financial, demographic and attitudinal variables in shaping landlord choices with respect to their property portfolios.

The paper is organised along the following lines. Section 2 reviews the literature on factors shaping landlords' housing supply decisions. Section 3 describes the data, sample design, measurement issues and modelling methodologies. Descriptive statistics on the characteristics of landlords are also presented. Section 4 presents results from two empirical exercises exploring landlords' propensity to retain rental investments, along with findings on the key factors driving landlord decisions. Section 5 concludes. 


\section{Background}

Quantitative studies of landlords' investment decisions tend to emphasise financial factors and market conditions (Shroder, 2001, for example), while qualitative studies such as Seelig et al. (2009) focus more on personal characteristics or investor attitudes that make certain individuals more inclined to include rental investments in personal wealth portfolios.

\section{Financial Drivers}

Economic models of personal investment decisions highlight after-tax returns to alternative investments and the composition and size of personal net wealth. Ioannides and Rosenthal (1994), for example, model investment decisions within a framework that allows identification of both consumption and investment demands for housing. Their results indicate that while consumption demand is driven by demographic variables, investment demand is more sensitive to financial variables such as income and wealth. Shroder (2001) finds that as the size of personal wealth portfolios increase households are more inclined to hold rental investments in portfolios. The fixed costs of acquiring real estate and its lumpy nature will deter their addition until household wealth has reached some threshold that allows investment in both real estate and more liquid assets that can buffer shocks. The possible importance of tax factors is signaled by a finding that those with higher MITRs are more likely to invest in rental property.

A potentially critical financial variable affecting rental investment decisions is user cost. The investor's user cost of capital is the hurdle rate that gross rental yields must at least equal if a competitive return is to be achieved, and will be important in determining whether rational investors' continue to hold property investments ${ }^{\text {ii }}$. Econometric estimates from Follain et al. (1993) show that user cost is a significant determinant of multifamily rental housing construction. Various studies have hypothesised that landlords pass on changes in user cost into rents. Blackley and Follain's (1996) empirics show that approximately half of any change in user cost is passed on into 
rents, though rent adjustments can take a long time.

Capital gains are a potential influence as those expecting healthy capital gains are more likely to retain investment properties. Capital gain is found to be one of the strongest motivating factors behind rental investment in Seelig et al.'s (2009) qualitative study, and important in ensuring satisfactory returns in the UK (Crook and Kemp, 2011, p99). Market competition will equalise rates of return across market segments and therefore segments with relatively low gross rental yields must reflect high expected capital gains as investors compete to acquire properties in these market segments. Using forward-looking present value models, Clark (1995) and Capozza and Seguin (1996) have found that properties realising higher future capital gains exhibit lower current gross rental yields.

The Australian investor can deduct rental losses from other sources of taxable income (negative gearing); though this tax shelter's continued presence in the tax code is repeatedly questioned (Fane and Richardson, 2004; Henry et al., 2009, p70), there is little empirical evidence on its housing market impacts. An exception is Babcock and Browett (1991) who use the 1985-87 quarantining of negative gearing (in Australia) to explore impacts on rental housing supply. There was a downturn in rental investment following the 1985 tax reforms and a recovery following full reinstatement in 1987. But the authors argue that these supply responses were largely due to factors other than negative gearing, with the latter a marginal influence on private rental supply. Wood and Kemp (2003) offer evidence suggesting that Australian taxation arrangements are not as preferential as might be thought when focusing only on negative gearing provisions. Respondents to the indepth interviews conducted by Seelig et al. (2009) seemed evenly divided on whether they would have invested in the absence of negative gearing. However, they note that negative gearing is a deliberate strategy of some investors, who refinance by cycling in and out of rental property investments to remain negatively geared. In the United States, real estate investors are able to take advantage of a $\$ 3000$ passive loss offset against other taxable income. However, Shroder (2001) 
found that once the $\$ 3000$ offset has been exceeded investors behave as though real estate is taxed unfavourably relative to other investments.

\section{Personal Characteristics and Attitudes}

Those analysing the role of financial factors typically assume that landlords are fully informed, rational investors. But survey findings such as those reported in Kemp and Rhodes (1997) study of Scottish landlords shed doubt on this assumption. Landlords are thought to be cautious, risk-averse wealth accumulators, preferring to tie up their savings in 'bricks and mortar', rather than shares and bonds where control over the underlying income generating assets is ceded to others. Surveys also find key demographic characteristics that include death in the family, presence of children, retirement status and divorce and separation to be correlated with rental investment. These demographics are not obviously associated with the financial factors driving fully informed rational investment decisions.

Death in the family commonly triggers bequests of property that create 'accidental' landlords who never considered rental investment as part of a deliberate wealth accumulation strategy. In the Kemp and Rhodes (1997) survey of landlords, $40 \%$ are found to have inherited their property. These 'accidental landlords' will have spent little time thinking through how their property inheritance should be used in wealth portfolio strategies, and tend to lease their properties while considering options. Windfalls will likely result in property biased wealth portfolios, particularly if recipients are already homeowners. If reducing that bias to achieve a more diversified portfolio, or releasing cash to meet pressing spending needs are common motives, accidental landlords will be short-term investors in the rental market.

Realising rental investments to meet household welfare needs is more probable if the landlord has children. Evidence reported in Seelig et al. (2009) suggests that the presence of children affects decisions to continue investing in rental housing. As children reach adulthood some 
investors plan to transfer property investments to their children, or sell up and use the equity to assist children into homeownership.

The life cycle model of consumption and saving posits that households will seek to smooth consumption in old age by saving and accumulating assets during their working lives, and drawing down on these assets once retired (Skinner, 1996; Kohler and Rossiter, 2005). Hence retirement should precipitate disposal of rental investments. In Australia there is an additional financial motive. Eligibility for state age pensions is governed by income and asset tests. While owneroccupied housing assets are exempt, the value of equity held in rental housing investments must be added to assessable assets. The landlord expecting a binding asset test may gain eligibility to the age pension by selling up as retirement approaches, spending the equity released, or rolling it into owner-occupied housing (the asset test hypothesis).

But there is a different group of older investors with relatively high incomes and wealth portfolios that rule out eligibility for the Australian age pension regardless of their rental investment holdings. Rental housing has the advantage of generating a regular (monthly) income stream to meet day-to-day expenses, an attribute not shared by shares or deposits with financial institutions ${ }^{\text {iii }}$. This will be a particularly important consideration for retirees lacking occupational pension entitlements, but a stock of income yielding assets that are being drawn on to meet living expenses in retirement.

As investors, couples have numerous advantages over singles that help them include and retain rental properties in wealth portfolios. Couples can pool resources and if both partners are salaried their capacity to leverage property acquisitions is typically superior to that of singles. Furthermore two income streams are less risky than one (Kohler and Rossiter, 2005). Separation and divorce requires the division of pooled savings and the loss of these advantages that will likely trigger realisation of rental property assets.

Property investment appeals to the risk-averse because it is perceived as a low risk tangible asset that can (in unregulated rental markets) be consumed by moving in and using it as a principal 
residence. The appeal of housing as a secure asset might be buttressed by a belief that housing assets are a hedge against inflation. Property investment is also attractive to the 'unsophisticated investor' as it is familiar 'bricks and mortar' that does not require the economic or financial knowledge that shares, bonds and more sophisticated financial investments might require (Seelig et al., 2009).

This discussion indicates that short-term landlords are typically accidental landlords with children, or singles that are the product of divorce and separation. Retirement has a complex relationship with landlord investment intentions. Those approaching retirement and in a position to rearrange their asset portfolio to ease binding pension asset tests are likely to be short-term landlords. On the other hand those relatively well-off landlords that have accumulated savings in assets other than occupational pensions will be more inclined to hold on to their rental properties post-retirement. Finally the cautious risk-averse landlord will favour retention of rental property investments in wealth portfolios because property returns are generally thought to be more secure.

\section{Method}

\subsection{Data and Sample Design}

Our analysis is conducted using the Household, Income and Labour Dynamics in Australia (HILDA) Survey, a panel survey that began in 2001 and tracks a nationally representative sample of Australian households over time, including Australian landlords and the duration of their rental investments $^{\mathrm{iv}}$. Moreover, it contains a range of variables on personal, attitudinal and financial characteristics that help enrich our understanding of landlord behaviours.

We conduct two empirical exercises using different sample designs. In the first we analyse the length of time over which landlords' retain their rental investments using a hazard rate approach.

The hazard rate exercise draws on the first investor spells of 1570 landlords with complete records from 2001 to 2006, and identified by whether they received rental income and were the legal owner 
of a second property ${ }^{\mathrm{v}}$. Rental income and whether the individual is the legal owner of a second property is reported in all waves, so we can make use of every wave of the HILDA Survey to identify spells of rental investment.

The second exercise estimates a regression model analysing determinants of landlord propensities to retain rental investments. Waves 2 (2002) and 6 (2006) of the HILDA Survey contain special wealth modules that record the distribution of household wealth between various asset classes, e.g. primary home, other property, superannuation, business, and financial instruments $^{\mathrm{vi}}$, vehicles and collectibles, as well as business debt, property-secured debt and unsecured debt ${ }^{\mathrm{vii}}$. These asset and debt values (in particular rental property) are required for the measurement of critical economic variables such as user cost. The regression modeling therefore uses only waves 2 and 6 of the Survey and a smaller 543 sample of persons who were landlords in 2002. Just over 50\% exit between 2002 and $2006^{\text {viii }}$.

While the unit of analysis is individuals some of the key variables used in the modeling are measured on an income unit or household basis ${ }^{\mathrm{ix}}$. We measure user cost and its main determinant (the landlord's MITR) on an income unit basis, because tax liabilities are calculated based on income unit characteristics such as whether one is partnered, and number of dependent children. Other variables such as wealth and debt are reported in HILDA on a household basis. To ensure measurement is uniform the household level variables are converted into income unit measures by assuming that wealth and debt are shared equally among adults belonging to the same household. All the income unit variable measures are assigned using an attribution approach where each person is linked with their matched income unit variable measure.

\subsection{Estimation Method, Model Specification and Variable Measurement}

The length of time landlords hold their rental investments is analysed using a hazard rate approach that estimates the probability of retaining an investment at time t conditional on 'survival' 
as an investor at t-1 (the survival rate). A complementary measure is the proportion of landlords in year $\mathrm{t}-1$ that realise rental investments in year $\mathrm{t}$ (the hazard rate); 344 spells, or $22 \%$ of the total, are ongoing at the end of the study time frame and therefore right censored. However the hazard rate calculations turn out to be maximum likelihood estimates of the discrete-time hazard function in the presence of right censoring (Singer and Willett, 2003, p331).

A probit model is employed to estimate the probability of landlords retaining their rental investments as a function of their personal characteristics and financial variables. The probit model is estimated with respect to whether landlords in 2002 exit the market by 2006 . To help address potential endogeneity issues the model is estimated as a function of landlord characteristics as measured in 2002.

Table 1 defines the variables experimented with in the analyses. These variables capture the motives that our literature review suggests are important in driving rental investments and are divided into four broad groups; socio-demographic characteristics, human capital characteristics, attitudes toward risk and financial drivers.

In the socio-demographic category we include variables representing presence of children, age, retirement status and marital status. The presence of children is grouped into four age bands. Age and retirement are included in our models via a continuous age variable and a retirement dummy variable.

Education qualification variables are used to distinguish between sophisticated and unsophisticated investors, but they have another interpretation as they reflect human capital and therefore the long run earnings potential of the person (Kohler and Rossiter, 2005). King and Leape (1998) find that the probability of ownership of an asset type group that includes real estate is increased by human capital (education, occupation) variables. Employment is represented by the proportion of time spent in paid work (unemployed) since leaving full-time education. Continuous employment will facilitate the accumulation of human capital, particularly experience.

Attitudes to risk and property investment are not elicited by the HILDA survey and so we 
resort to proxy measures. Possession of a life insurance policy and regular saving behaviour should be correlated with risk aversion and such people are inclined to choose conservative investments such as property.

Financial drivers include measures of superannuation balances and debt not secured against property. The need to diversify investments or spread financial risks may be a motive for investment in property. Those with large amounts of wealth tied up in superannuation are then apt to hang on to property investments. Investors with high levels of other debt are in more precarious circumstances in the event of unanticipated adverse shocks (e.g. loss of job, business failure); their survival as investors is threatened as compared to the investor with little debt. We add the negatively geared status of rental investors to capture churning effects. The investor's user cost and gross rental yield are both expected to have large negative impacts as key financial drivers in rational investor models of decision making.

Considerable care has been taken in estimating each landlord's user cost. In the present context they represent the investor's costs (maintenance, interest payments, the opportunity cost of equity capital and so on) of holding an asset for one year, net of the capital appreciation accrued over the course of that year, and after taking into account the tax treatment of net rental income, capital gains, land and transaction taxes ${ }^{\mathrm{x}}$. We measure each of these components of user cost using a housing market microsimulation model containing key Federal and State tax and transfer parameters likely to affect landlords' after-tax economic costs (Wood and Ong, 2008). Key parameter values and assumptions are listed in appendix table A1. The user costs of Australian rental investors have two key features. Firstly, the symmetric tax treatment of rental income and rental losses means that user cost is independent of the investor's loan-value ratio. Secondly, the taxation of capital gains at $50 \%$ of a landlord's marginal tax rate ensures that user cost is a declining 
function of their marginal tax rate.

A noteworthy omission from the vector of financial variables is income. The absence of an income variable is also a feature of tenure choice econometric models estimated using Australian data (Bourassa and Yin, 2006; Hendershott et al., 2009). An investor's user cost of capital reflects their tax bracket, which in turn is determined by income, hence its omission. Expectations of future income might be relevant, but such expectations should be captured by the model's human capital variables.

[Insert Table 1 here]

\subsection{Descriptive Statistics}

Table 2 compares key landlord characteristics to those of all adult Australians using the 2006 wave of the HILDA Survey, where there are 865 landlords. Using population weights we obtain a 2006 estimate of over 1 million Australian landlords. This is equivalent to $7.3 \%$ of the adult population; since some individual landlords belong to the same household, the number of property portfolios is smaller at 612 , equivalent to a population estimate of 643,000 . We find landlords are distinctly different from the general Australian population. Over half of residential landlords are middle-aged (35-54 years) compared to 38\% of all Australians. Landlords are also much more inclined to marry (69\% compared to 52\%) and have dependent children than the typical Australian adult. Individuals with superior qualifications, and active in the labour market, are overrepresented among landlords. Landlords are better off in economic terms; their average disposable incomes (average wealth) are one and a half times (more than twice) those of the average Australian. However, landlords are also more highly geared; landlord debt levels exceed three times the typical indebtedness among the adult population. Finally, in keeping with comparisons based on income, landlords MITRs are more skewed toward higher tax brackets than those of typical 
Australians.

[Insert Table 2 here]

With respect to key financial drivers and property values key features include a variation in mean user costs that increase from $7.6 \%$ in the lowest user cost quintile to $8.5 \%$ in the highest quintile; this is equivalent to a $\mathrm{A} \$ 4763$ per annum difference at the mean property value of $\mathrm{A} \$ 529230$. Gross rental yields correlate with user cost, rising from $4.3 \%$ to $5.9 \%$ over the same user cost quintiles. Those with relatively high user costs charge higher rents relative to property values. These are very clear patterns and documented in earlier work that showed the importance of tax arrangements in shaping these patterns (Wood and Tu, 2004).

\section{Results}

\subsection{Hazard Rates}

Table 3 is a 'life table' that tracks the event histories of rental investors from the first year of their spell of rental investment, through to the end of the data collection period. We define the beginning of time as the first wave during which a person is recorded as holding a rental property, and label it year 0; interest focuses on whether, and when, the spell of rental investment ends. Time, measured in one year intervals, is recorded in column 1. The following information is recorded in subsequent columns:

the number of landlords holding rental properties during the year (column 2);

the number of landlords realising their rental investment during the year (column 3) and, the number of landlords with right censored rental investment spells at the end of that year (column 4).

In year 0 , all 1,570 persons hold rental properties and 113 landlord spells are censored because their spell began in Wave 6 (2006), the final year of the data collection period. This leaves 
$1,457(1,570-113)$ to enter the next time interval, year 1 , and so on. The number of landlords entering each successive time period is the 'at risk' set comprising those who might realise their rental investment during that time interval. By the start of year 5, there are still 376 landlords in the 'at risk' set, but most are censored cases (344), with only 32 realising their rental investment during that year. The hazard rate in column 5 is a key measure of the likelihood of realising a rental investment. It is a measure of the conditional probability that a randomly selected landlord will relinquish his/her rental investment in year $t$, given retention of their rental investment in time periods preceding year $t$.

Table 3 shows that a quarter of landlords are expected to realise their rental investment during year 1 . However, there is a sharp decline in the hazard rate to 0.085 by Year 5, so the longer a landlord holds rental property, the less likely s/he is to realise property investments (negative duration dependence). The survival rate in year 5 is quite high, at over $40 \%$. There is a group of investors that 'stay the course', and are a source of secure accommodation. If a tenant with low mobility intentions is lucky enough to lease from such an investor, their accommodation will be secure in the medium to long run. This has a wider significance in light of the ontological security and psycho-social benefits individuals derive from their home (Dupuis and Thorns, 1998).

[Insert Table 3 here]

\subsection{Probit Model of Landlord Status in 2006}

Table 4 reports probit regression results. There is a 543 sample of investors in 2002; a slight majority (286 or $52.6 \%$ ) exit the market by 2006 , but a sizeable minority ( 257 or $47.3 \%$ ) survive. It turns out that, with two notable exceptions, demographic and attitudes to risk variables are statistically insignificant. The exceptions, and they confirm evidence from qualitative work reported 
in Seelig et al. (2009), is age and retirement status. Younger investors are less attached to rental investments and middle-aged investors are more likely to stick with their investments. However, once retired, there is a sharp increase in the likelihood of exit from rental investments; the marginal effect estimates (see table 4) indicate that a retired person has a 23 percentage point higher probability of selling up at any point in the investment spell. Retired persons with pressing spending needs, or few alternative investments to meet emergencies might be selling up to invest in more liquid assets. Alternatively, pension asset tests could prompt realisation as retired investors cash out accumulated wealth, and enjoy the 'high life' knowing that they can fall back on the Age Pension once their wealth has been spent. There is some evidence to support the asset test hypothesis. Among the retired who realised their investments, almost $40 \%$ were eligible for an income support payment by 2006 ; the proportion is much lower (at $12.8 \%$ ) among the retired who retained their investments. Of the remaining non-financial variables, labour market history variables are statistically significant. Continuous spells of employment cushion investors with respect to adverse economic shocks; these investors are better able to ride out the bad times without selling assets.

The size and statistical significance of a majority of the financial variables suggest that they do matter. The 2002 gross rental yield has a statistically significant negative coefficient as predicted by the forward looking present value model. The marginal effect estimates suggest that a one percentage point higher gross rental yield is associated with a 1.2 percentage point lower probability of survival as an investor in 2006.

The model confirms the importance of negative gearing status. A negative marginal effect estimate of 11.5 percentage points is very large given that $53 \%$ of our sample of investors survived as investors in 2006. There are two possible reasons; highly leveraged investors are more vulnerable to shocks. The alternative interpretation suggests that negatively geared investors are churning in and out of rental investments to preserve tax shelter benefits (Seelig et al., 2009; Wood and Ong, 2010). Regardless of the reason it seems that negative gearing provisions in the tax system adversely impact tenure security in rental housing. 
It turns out that the user cost variable is also very influential in the probit model - a 1 percentage point increase in user cost has a marginal effect estimate of 10.3 percentage points. However, there are few investors with user costs that differ by as much as one percentage point so this perhaps exaggerates the importance of user cost. A one standard deviation increase in user cost ( 0.461 percentage points) lowers the probability of survival in 2006 by 4.4 percentage points, a substantial but relatively modest impact. Nevertheless it seems that higher after-tax economic costs eat into returns and persuade some investors to exit the market.

The significance of these financial variables is their suggestion that government fiscal and monetary policy changes will help shape decisions about whether to remain an investor, since interest rate and tax parameters are important in determining investors' user costs and their negative gearing status. These will in turn drive changes in housing supply and affordability in rental markets.

There is a potentially important caveat to these findings ${ }^{\mathrm{xi}}$. We know the survival rates of investors, but for those who did not become investors we have no measure of survival. The dependent variable is then censored and regression estimates can be biased. Table 5 reports the second stage results of an estimation procedure that follows the first stage estimation of a probit model distinguishing those individuals that had landlord status in 2002, and those who held no rental properties in wealth portfolios ${ }^{x i i}$. Key findings with respect to the gross rental yield and negative gearing financial variables are unchanged, with marginal effect and statistical significance levels unaffected. The same outcomes are evident for the labour market variable $\%$ of time in paid work, and the retirement status demographic variable. But user cost and age become insignificant. In the first stage regressions both these variables are highly statistically significant - those with high user cost (and therefore high required rates of return) and younger people (who are more likely to be credit constrained) have a low propensity to invest in rental housing, and these patterns could well account for the spurious significance levels achieved in the single equation regression 
estimates.

[Insert Tables 4 and 5 here]

\section{Conclusion}

This is the latest in a series of studies that examine the importance of after-tax economic costs (user cost) and taxation arrangements to rents and the housing decisions of Australian landlords (Wood and Watson, 2001; Wood and Kemp, 2003; Wood and Tu, 2004). These studies use different methods, alternative data sets, and have been conducted at different times in economic cycles. This is the first instance of panel data being used, and it is also novel because the investment decisions of Australian landlords have not been the subject of econometric modelling before this study. The model estimates confirm the importance of financial variables and therefore endorse the widely held view that government fiscal and monetary policy settings will shape rental housing investment decisions. Our findings suggest that the potential impact of fiscal and monetary policy parameters on the supply-side of the rental housing market should be carefully taken into account. The impacts are not always obvious. One curious illustration is the application of asset means tests governing eligibility to the Australian state age pension, which appear to trigger disposal of rental property investments as investors transition into retirement.

The precarious nature of private rental housing is a disadvantage to immobile tenant households, particularly parents with school-age children since child care and schooling arrangements benefit from residential stability. There are mutual gains if markets match such households with investors that are committed long-term landlords. Unfortunately, our findings suggest that there is no easy way to ensure such matches in a market setting, since some of the more important variables that distinguish short and longer term landlords are unobservable. One example is negative gearing status. It turns out that negatively geared rental investors are more likely to terminate leases at any point in an investment spell. 
These conclusions may have relevance in other countries. The use of tax expenditures to promote the supply of private rental housing is widespread in developed countries, and they often take the form of deductions for borrowing expenses (see Haffner et al., 2009). These measures will tend to favour leveraged private landlords at the expense of equity oriented investors. Since the latter appear to be longer term rental investors, such measures will undermine tenants' security of tenure. There is also evidence in the UK that leveraged landlords are more likely to regard their property as a source of capital gain (see Crook and Kemp, 2011, table 7.7). Extending increasingly generous tax expenditures to borrowing expenses could then attract more investment oriented landlords into private rental markets that increase the risk of property bubbles in boom periods.

\section{Appendix}

[Insert Table A1 here]

\section{References}

Australian Bureau of Statistics (1997) Survey of Income and Housing Costs, Australia: User Guide, Cat. No. 6553.0. Canberra: Australian Bureau of Statistics.

Babcock, B. and Browett, M. (1991) The Responsiveness of the Private Rental Sector in Australia to Changes in Commonwealth Taxation Policy, Housing Studies, 6(3), pp. 182-192.

Blackley, D. M. and Follain, J. R. (1996) In Search of Empirical Evidence that Links Rent and User Cost, Regional Science and Urban Economics, 26(3-4), pp. 409-431.

Bourassa, S.C. and Yin, M. (2006) Housing Tenure Choice in Australia and the United States: Impacts of Alternative Subsidy Policies, Real Estate Economics, 34, pp. 303-328.

Capozza, D. R. and Seguin, P. J. (1996) Expectations, Efficiency and Euphoria in the Housing Market, Regional Science and Urban Economics, 26(3-4), pp. 369-386.

Clark, T. E. (1995) Rents and Prices of Housing across Areas of the United States: A Cross-Section Examination of the Present Value Model, Regional Science and Urban Economics, 25, pp. 
237-247.

Crook, T. and Kemp, P. A. (2011) Transforming Private Landlords; Housing, Markets and Public Policy. Oxford: Wiley-Blackwell.

De Leeuw, F. and Ozanne, L. (1981) Housing, in: H. Aaron and J. Pechman (Eds.) How Taxes Affect Economic Behaviour, pp. 283-319. Washington, DC: The Brooking Institution.

Dockery, A. M., Kendall, G., Li, J., Mahendran, A., Ong, R. and Strazdins, L. (2010) Housing and Children's Development and Wellbeing: A Scoping Study, Final Report. Melbourne: Australian Housing and Urban Research Institute.

Dupuis, A. and Thorns D. C. (1998) Home, Home Ownership and the Search for Ontological Security, Sociological Review, 46(1), pp. 24-47.

Fane, G. and Richardson, M. (2004) Negative Gearing Redux, Agenda, 11(3), pp. 211-222.

Fisher, J. D. and Lentz, G. H. (1986) Tax Reform and the Value of Real Estate Income Property, American Real Estate and Urban Economics Association Journal, 14(2), pp. 287-315.

Follain, J. R., Hendershott, P. H. and Ling, D. C. (1987) Understanding the Real Estate Provisions of Tax Reform: Motivation and Impact, National Tax Journal, 3, pp. 363-72.

Follain, J. R., Leavens, D. R. and Velz, O. T. (1993) Identifying the Effects of Tax Reform on Multifamily Rental Housing, Journal of Urban Economics, 34, 275-298.

Haffner, M., Hoekstra, J., Oxley, M. and van der Heijden, H. (2009) Bridging the Gap Between Social and Market Rented Housing in Six European Countries? Housing and Urban Policy Studies 33. Amsterdam: IOS Press BV.

Hendershott, P. H. and Ling, D. C. (1984) Prospective Changes in Tax Law and the Value of Depreciable Real Estate, Journal of the American Real Estate and Urban Economics Association, 12(3), pp.297-317.

Hendershott, P. H., Ong, R., Wood, G.A. and Flatau, P. (2009) Marital History and Home Ownership: Evidence from Australia, Journal of Housing Economics, 18(1), pp. 13-24.

Henry, K., Harmer, J., Piggott, J., Ridout, H. And Smith, G. (2009) Australia's Future Tax System, 
Report to the Treasurer, Available: taxreview.treasury.gov.au

Ioannides, Y. M. and Rosenthal, S. S. (1994) Estimating the Consumption and Investment Demands for Housing and their Effect on Housing Tenure Status, The Review of Economics and Statistics, 76 (1), pp. 127-141.

Kemp, P. A. and Rhodes, D. (1997) The Motivations and Attitudes to Letting of Private Landlords in Scotland, Journal of Property Research, 14(2), pp. 117-132.

King, M. A. and Leape, J. I. (1998) Wealth and Portfolio Composition: Theory and Evidence, Journal of Public Economics, 69, pp. 155-193.

Kohler, M. and A. Rossiter (2005) Property Owners in Australia: Snapshot Research, Discussion Paper 2005-03, Reserve Bank of Australia.

Larsen, E. R. and Sommervoll, D. E. (2009) The Impact on Rent from Tenant and Landlord Characteristics and Interaction, Regional Science and Urban Economics, 39(3), pp.316-322.

MacNevin, A. S. (1997) Marginal Effective Tax Rates on Canadian Rental Housing Investments: An Asset Pricing Model Approach, Public Finance Review, 25(3), pp.306-326.

Seelig, T., Thompson, A., Burke, T., Pinnegar, S., McNelis, S. and Morris, A. (2009) Understanding What Motivates Households to Become and Remain Investors in the Private Rental Market, Final Report. Melbourne: Australian Housing and Urban Research Institute.

Shroder, M. (2001) What Makes a Landlord? Ownership of Real Estate by US Households, Urban Studies, 38(7), pp. 1069-1081.

Singer, J.D. and Willett, J. B. (2003) Applied Longitudinal Data Analysis: Modelling Change and Event Occurrence. Oxford: Oxford University Press.

Skinner, J. S. (1996) Is Housing Wealth a Side Show?, in: Wise, D. (Eds.) Advances in the Economics of Aging, pp. 241-268. Chicago: University of Chicago Press.

Wood, G. and Kemp, P.A. (2003) The Taxation of Australian Landlords: Would the British Tax Treatment of Rental Investments Increase Tax Burdens if Introduced in Australia? Urban Studies, 40(4), pp. 747-765. 
Wood, G. and Ong, R. (2008) Redesigning AHURIs Australian Housing Market Microsimulation Model, Report. Melbourne: Australian Housing and Urban Research Institute.

Wood, G. and Tu, Y. (2004) Are There Clientele Groups Among Investors In Rental Housing?, Real Estate Economics, 32(2), pp. 413-436.

Wood, G. and Watson, R. (2001) Marginal Suppliers, Taxation, and Rental Housing: Evidence from Microdata, Journal of Housing Research, 12(1), pp. 91-114.

Wood, G. Ong, R. and Stewart, M. (2010) Housing Taxes and the Supply of Private Rental Housing, in: Stewart, M. (eds.) Housing and Tax Policy, 163-180. Melbourne: Australian Tax Research Foundation.

Wulff, M, Dharmalingam, A., Reynolds, M. and Yates, J. (2009) Australia's Private Rental Market: Changes (2001-2006) in the Supply of, and Demand for, Low Rent Dwellings, Positioning Paper. Melbourne: Australian Housing and Urban Research Institute. 
Table 1: List of variables

\begin{tabular}{|c|c|c|}
\hline Category & $\begin{array}{l}\text { Continuous } \\
\text { or Binary }\end{array}$ & Variable $^{\mathrm{a}}$ \\
\hline \multicolumn{3}{|l|}{ Socio-demographic } \\
\hline \multirow[t]{5}{*}{ Marital status } & Binary & Equals 1 if continuously married (reference category) \\
\hline & Binary & Equals 1 if de facto \\
\hline & Binary & Equals 1 if separated, divorced or widowed \\
\hline & Binary & Equals 1 if single never married \\
\hline & Binary & Equals 1 if remarried \\
\hline \multirow{4}{*}{$\begin{array}{l}\text { Number of resident and non- } \\
\text { resident children }\end{array}$} & Continuous & Number of children aged $0-4$ years \\
\hline & Continuous & Number of children aged 5-14 years \\
\hline & Continuous & Number of children aged 15-24 years \\
\hline & Continuous & Number of children aged $25+$ years \\
\hline Age & Continuous & In years \\
\hline Retirement status & Binary & Equals 1 if a person has retired \\
\hline \multicolumn{3}{|l|}{ Human capital } \\
\hline \multirow[t]{3}{*}{ Education } & Binary & Equals 1 if highest qualification is bachelor degree or higher \\
\hline & Binary & Equals 1 if highest qualification is another post-school qualification \\
\hline & Binary & $\begin{array}{l}\text { Equals } 1 \text { if highest qualification not a post-school qualification } \\
\text { (reference category). }\end{array}$ \\
\hline \multirow{2}{*}{$\begin{array}{l}\text { Labour market history since } \\
\text { leaving full-time education }\end{array}$} & Continuous & Percent of time in paid work \\
\hline & Continuous & Percent of time unemployed \\
\hline Attitudinal variables & & \\
\hline
\end{tabular}




\begin{tabular}{|c|c|c|}
\hline Category & $\begin{array}{l}\text { Continuous } \\
\text { or Binary }\end{array}$ & Variable $^{\mathbf{a}}$ \\
\hline Life insurance & Binary & Equals 1 if own life insurance \\
\hline Financial risk-taking & Binary & Equals 1 if unwilling to take financial risks \\
\hline Savings time horizon & Binary & Equals 1 if savings time horizon is less than one year \\
\hline Saving habit & Binary & Equals 1 if save regularly each month \\
\hline Financial drivers & & \\
\hline Superannuation wealth & Continuous & 2002 level of superannuation wealth/AUD $\$ 100,000$. \\
\hline Non-property secured debt & Continuous & 2002 level of debt not secured by property/AUD $\$ 100,000$. \\
\hline Expectation of capital gains & Continuous & Gross rental yield in percent ${ }^{b}$ \\
\hline Negatively geared status & Binary & Equals 1 if negatively geared in all waves \\
\hline User cost & Continuous & $\begin{array}{l}\text { Landlord's after-tax economic costs as a } \% \text { of property value } \\
\text { computed using a housing market microsimulation model }{ }^{\mathrm{b}} \text { (see Table } \\
\text { A1 for details). }\end{array}$ \\
\hline
\end{tabular}

Notes:

Other variables that were experimented with but proved to be insignificant include a Herfindahl index measure of wealth portfolio diversification; whether Age Pension asset tests are binding as a person aged 55 or over approaches a retirement age of 65 years; recent capital gain as measured by the lagged change in rental property value; and ethnicity. We cannot identify the value of individual properties; investors only report the aggregate value of rental property portfolios. Our measures of rental yield and user cost are therefore based on rental property portfolios. However, earlier surveys of Australian rental investors have established that the majority own only one rental property. For example, using data from the 1997 Rental Investors Survey, Wood and Tu (2004) found that 79.7\% of rental investors held single property portfolios in that year. 
Table 2: Characteristics of landlords, 2006

\begin{tabular}{|c|c|c|}
\hline Characteristics & Landlords & All Adults \\
\hline \multicolumn{3}{|l|}{ Age band $(\%)$} \\
\hline$<35$ yrs & $14.6 \%$ & $30.6 \%$ \\
\hline $35-54$ yrs & $53.5 \%$ & $38.1 \%$ \\
\hline $55+\mathrm{yrs}$ & $31.9 \%$ & $31.2 \%$ \\
\hline \multicolumn{3}{|l|}{ Marital status (\%) } \\
\hline Legally married & $69.0 \%$ & $51.7 \%$ \\
\hline De facto & $13.3 \%$ & $13.3 \%$ \\
\hline Separated & $1.8 \%$ & $3.0 \%$ \\
\hline Divorced & $5.4 \%$ & $6.9 \%$ \\
\hline Widowed & $3.2 \%$ & $6.0 \%$ \\
\hline Single never married & $7.2 \%$ & $19.0 \%$ \\
\hline \multicolumn{3}{|c|}{ Presence of dependent children (\%) } \\
\hline No dependent children & $57.3 \%$ & $66.2 \%$ \\
\hline Have dependent children & $42.7 \%$ & $33.8 \%$ \\
\hline \multicolumn{3}{|l|}{ Highest qualification (\%) } \\
\hline Bachelor degree or higher & $35.5 \%$ & $21.7 \%$ \\
\hline Other post-school qualification & $32.9 \%$ & $31.7 \%$ \\
\hline No post-school qualification & $31.6 \%$ & $46.5 \%$ \\
\hline \multicolumn{3}{|l|}{ Labour force status (\%) } \\
\hline Employed full-time & $62.4 \%$ & $47.2 \%$ \\
\hline Employed part-time & $21.6 \%$ & $18.6 \%$ \\
\hline
\end{tabular}




\begin{tabular}{|c|c|c|}
\hline Unemployed & $1.0 \%$ & $2.9 \%$ \\
\hline Not in the labour force & $14.9 \%$ & $31.3 \%$ \\
\hline Income and assets (A\$) & & \\
\hline Mean personal annual disposable income & 49,448 & 32,086 \\
\hline Mean gross wealth & $1,625,972$ & 620,958 \\
\hline Mean gross debt & 353,343 & 97,455 \\
\hline Mean MITR $(\%)$ & $28.3 \%$ & $21.7 \%$ \\
\hline$\%$ in MITR bracket & & \\
\hline $0 \%$ & $7.5 \%$ & $14.8 \%$ \\
\hline $15 \%$ & $15.3 \%$ & $32.6 \%$ \\
\hline $30 \%$ & $50.9 \%$ & $42.6 \%$ \\
\hline $40 \%$ & $21.5 \%$ & $8.6 \%$ \\
\hline $45 \%$ & $4.9 \%$ & $1.4 \%$ \\
\hline
\end{tabular}

Source: Authors' own calculations from the HILDA Survey wave 6 
Table 3: Rental investment spells in the housing market

\begin{tabular}{|c|c|c|c|c|c|}
\hline [1] & [2] & [3] & [4] & [5] & [6] \\
\hline Year $^{\mathrm{a}}(\mathrm{t})$ & $\begin{array}{l}\text { Number of rental } \\
\text { investors at start of } \\
\text { year (T) }\end{array}$ & $\begin{array}{l}\text { Number that realised } \\
\text { rental investment } \\
\text { during the year }(\mathrm{N})\end{array}$ & $\begin{array}{l}\text { Number } \\
\text { censored }^{\mathbf{b}} \text { at end } \\
\text { of year }\end{array}$ & $\begin{array}{l}\text { Hazard rate } \\
H_{t}=N_{t} / T_{t}\end{array}$ & $\begin{array}{l}\text { Survival rate } \\
\mathbf{S}_{\mathrm{t}}=\mathbf{S}_{\mathrm{t}-1}\left(\mathbf{1}-\mathrm{H}_{\mathrm{t}}\right)\end{array}$ \\
\hline 0 & 1570 & 0 & 113 & & 1.000 \\
\hline 1 & 1457 & 375 & 96 & 0.257 & 0.743 \\
\hline 2 & 986 & 186 & 91 & 0.189 & 0.603 \\
\hline 3 & 709 & 114 & 80 & 0.161 & 0.506 \\
\hline 4 & 515 & 54 & 85 & 0.105 & 0.453 \\
\hline 5 & 376 & 32 & 344 & 0.085 & 0.414 \\
\hline
\end{tabular}

Source: Authors' calculations using the HILDA Survey waves 1-6

Notes:

1. The wave when a person is first recorded as a rental investor is labelled year 0 because we do not know whether the person realised his/her rental investment until recorded in the following wave, which is then labelled year 1.

2. Censored means that year $t+1$ occurred after the end of the data collection period. For example, a first spell of rental investment that begins in wave 6 will inevitably be censored at the end of year 0 because wave 6 is the last wave of data collection. 
Table 4: Probit Model Estimates: Probability of 2002 investors retaining rental investment in 2006

\begin{tabular}{|c|c|c|c|c|c|}
\hline \multicolumn{2}{|l|}{ Explanatory variables } & Coef. & $\begin{array}{l}\text { Std. } \\
\text { error }\end{array}$ & P-value & $\begin{array}{l}\text { Marg. effect } \\
\text { (\% pt) }\end{array}$ \\
\hline \multirow{4}{*}{ (Continuously married omitted) } & De facto & 0.063 & 0.181 & 0.729 & 2.5 \\
\hline & Divorced, separated or widowed & 0.132 & 0.223 & 0.552 & 5.3 \\
\hline & Single never married & -0.008 & 0.280 & 0.978 & -0.3 \\
\hline & Remarried & -0.088 & 0.163 & 0.591 & -3.5 \\
\hline \multirow[t]{4}{*}{ Number of children } & Aged $0-4$ yrs & -0.061 & 0.138 & 0.658 & -2.4 \\
\hline & Aged 5-14 yrs & 0.025 & 0.073 & 0.735 & 1.0 \\
\hline & Aged 15-24 yrs & 0.026 & 0.074 & 0.727 & 1.0 \\
\hline & Aged 25+ yrs & -0.003 & 0.069 & 0.97 & -0.1 \\
\hline \multirow[t]{2}{*}{ Retirement-related factors } & Age (yrs) & 0.015 & 0.008 & 0.063 & 0.6 \\
\hline & Whether retired & -0.596 & 0.219 & 0.006 & -22.5 \\
\hline Highest qualification & Bachelor degree or higher & 0.017 & 0.147 & 0.906 & 0.7 \\
\hline (No post-school qual. omitted) & Other post-school qual. & -0.056 & 0.141 & 0.695 & -2.2 \\
\hline Labour market history since left & $\%$ time in paid work & -0.007 & 0.003 & 0.026 & -0.3 \\
\hline full-time education & $\%$ time unemployed & -0.025 & 0.016 & 0.134 & -1.0 \\
\hline \multirow[t]{4}{*}{ Attitudinal variables } & Whether own life insurance & -0.206 & 0.149 & 0.167 & -8.1 \\
\hline & $\begin{array}{l}\text { Whether unwilling to take } \\
\text { financial risks }\end{array}$ & 0.031 & 0.141 & 0.825 & 1.2 \\
\hline & $\begin{array}{l}\text { Whether savings time horizons is } \\
<1 \text { year }\end{array}$ & -0.126 & 0.142 & 0.376 & -5.0 \\
\hline & $\begin{array}{l}\text { Whether save regularly each } \\
\text { month }\end{array}$ & 0.210 & 0.127 & 0.098 & 8.4 \\
\hline
\end{tabular}




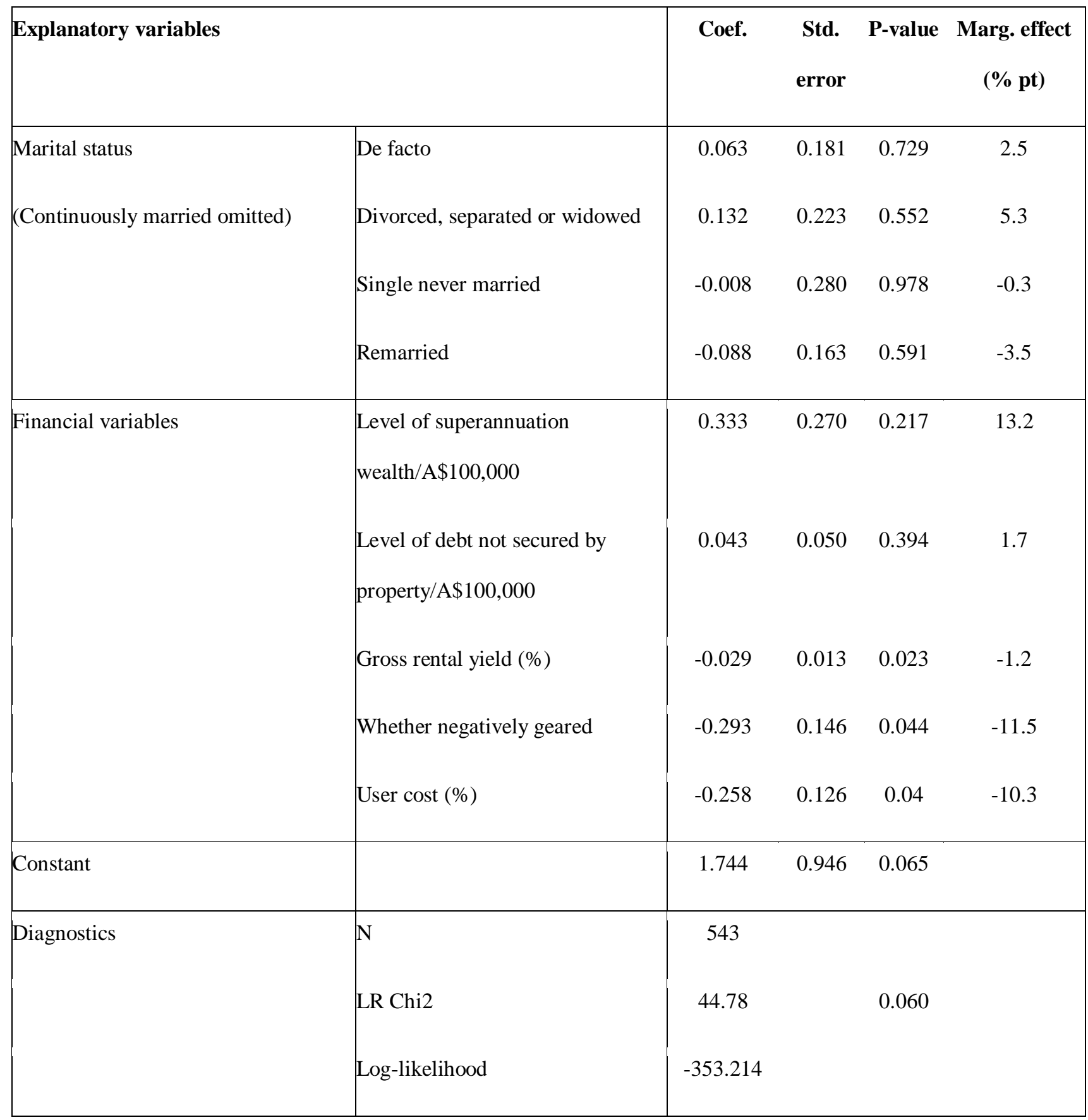

Source: Authors' calculations using the HILDA Survey waves 2 and 6 
Table 5: Second Stage Probit Model Estimates: Probability of 2002 investors retaining rental investment in 2006

\begin{tabular}{|c|c|c|c|c|c|}
\hline Explanatory variables & & Coef. & $\begin{array}{c}\text { Robust } \\
\text { std. } \\
\text { error }\end{array}$ & $\begin{array}{c}\text { P- } \\
\text { value }\end{array}$ & $\begin{array}{l}\text { Marg. } \\
\text { effect } \\
(\% \text { pt })\end{array}$ \\
\hline $\begin{array}{l}\text { Marital status } \\
\text { (Continuously married omitted) }\end{array}$ & $\begin{array}{l}\text { De facto } \\
\text { Divorced, separated or widowed } \\
\text { Single never married } \\
\text { Remarried }\end{array}$ & $\begin{array}{r}0.018 \\
0.187 \\
0.031 \\
-0.089\end{array}$ & $\begin{array}{l}0.187 \\
0.232 \\
0.290 \\
0.164\end{array}$ & $\begin{array}{l}0.923 \\
0.422 \\
0.914 \\
0.586\end{array}$ & $\begin{array}{r}0.007 \\
0.074 \\
0.012 \\
-0.035\end{array}$ \\
\hline Number of children & $\begin{array}{l}\text { Aged } 0-4 \text { yrs } \\
\text { Aged } 5-14 \text { yrs } \\
\text { Aged } 15-24 \text { yrs } \\
\text { Aged } 25+\text { yrs }\end{array}$ & $\begin{array}{l}-0.048 \\
0.026 \\
-0.013 \\
0.022\end{array}$ & $\begin{array}{l}0.136 \\
0.073 \\
0.078 \\
0.071\end{array}$ & $\begin{array}{l}0.726 \\
0.719 \\
0.870 \\
0.760\end{array}$ & $\begin{array}{l}-0.019 \\
0.011 \\
-0.005 \\
0.009\end{array}$ \\
\hline Retirement-related factors & $\begin{array}{l}\text { Age }(\mathrm{yrs}) \\
\text { Whether retired }\end{array}$ & $\begin{array}{l}0.009 \\
-0.516\end{array}$ & $\begin{array}{l}0.009 \\
0.226\end{array}$ & $\begin{array}{l}0.343 \\
0.023\end{array}$ & $\begin{array}{l}0.004 \\
-0.197\end{array}$ \\
\hline $\begin{array}{l}\text { Highest qualification } \\
\text { (No post-school qual. omitted) }\end{array}$ & $\begin{array}{l}\text { Bachelor degree or higher } \\
\text { Other post-school qual. }\end{array}$ & $\begin{array}{l}-0.097 \\
-0.109\end{array}$ & $\begin{array}{l}0.170 \\
0.149\end{array}$ & $\begin{array}{l}0.569 \\
0.465\end{array}$ & $\begin{array}{l}-0.039 \\
-0.043\end{array}$ \\
\hline $\begin{array}{l}\text { Labour market history since left } \\
\text { full-time education }\end{array}$ & $\begin{array}{l}\% \text { time in paid work } \\
\% \text { time unemployed }\end{array}$ & $\begin{array}{l}-0.009 \\
-0.020\end{array}$ & $\begin{array}{l}0.003 \\
0.021\end{array}$ & $\begin{array}{l}0.006 \\
0.329\end{array}$ & $\begin{array}{l}-0.004 \\
-0.008\end{array}$ \\
\hline Attitudinal variables & $\begin{array}{l}\text { Whether own life insurance } \\
\text { Whether unwilling to take } \\
\text { financial risks } \\
\text { Whether savings time horizons } \\
\text { is }<1 \text { year } \\
\text { Whether save regularly each } \\
\text { month }\end{array}$ & $\begin{array}{l}-0.238 \\
0.155 \\
0.027 \\
0.172\end{array}$ & $\begin{array}{l}0.149 \\
0.163 \\
0.174 \\
0.128\end{array}$ & $\begin{array}{l}0.110 \\
0.342 \\
0.877 \\
0.181\end{array}$ & $\begin{array}{l}-0.094 \\
0.062 \\
0.011 \\
0.068\end{array}$ \\
\hline Financial variables & $\begin{array}{l}\text { Level of superannuation } \\
\text { wealth/A } \$ 100,000 \\
\text { Level of debt not secured by } \\
\text { property/A } \$ 100,000 \\
\text { Gross rental yield (\%) } \\
\text { Whether negatively geared }\end{array}$ & $\begin{array}{l}-0.031 \\
-0.288\end{array}$ & $\begin{array}{l}0.287 \\
0.065 \\
0.014 \\
0.148\end{array}$ & $\begin{array}{l}0.606 \\
0.029 \\
0.051\end{array}$ & $\begin{array}{l}0.089 \\
-0.013 \\
-0.012 \\
-0.113\end{array}$ \\
\hline
\end{tabular}




\begin{tabular}{|l|l|cccc|} 
& User cost (\%) & -0.208 & 0.133 & 0.116 & -0.083 \\
\hline Inverse Mills ratio & & -0.569 & 0.381 & 0.136 & -0.226 \\
\hline Constant & & 2.870 & 1.174 & 0.014 & \\
\hline Diagnostics & $\mathrm{N}$ & 543 & & & \\
& LR Chi2 & 45.18 & & 0.006 & \\
& Log-likelihood & -352.505 & & & \\
& & & & & \\
& & & & & \\
\end{tabular}

Source: Authors' calculations using the HILDA Survey waves 2 and 6 
Table A1: Components of after-tax economic cost under 2006 tax arrangements

\begin{tabular}{|c|c|}
\hline User cost parameters & Parameter value \\
\hline Holding period & 10 years \\
\hline Depreciation rate & $1.4 \%$ \\
\hline Interest rate & $7.95 \%$ (banks' home loan rate in 2006-07) \\
\hline House price appreciation rate & $3.5 \%$ \\
\hline Agency rate & $11 \%$ \\
\hline Brokerage fees & $3.5 \%$ \\
\hline Building insurance & $0.2 \%$ of building value \\
\hline Maintenance cost & $\begin{array}{l}\text { Mean expenditure by property value/State segment, obtained from the } \\
1997 \text { Rental Investors Survey }\end{array}$ \\
\hline Property taxes & $\begin{array}{l}\text { Means of property taxes as a percent of property value by location from } \\
\text { the 2002-03 Survey of Income and Housing Costs }\end{array}$ \\
\hline Land taxes & $\begin{array}{l}\text { Based on state/territory land tax schedule and assumption that land } \\
\text { value is } 57 \%(39 \%) \text { of property value in metro (non-metro) regions } \\
\text { based on the Victorian Value-General's valuations database }\end{array}$ \\
\hline $\begin{array}{l}\text { Stamp duties and mortgage in } \\
\text { premiums }\end{array}$ & Zero (upfront costs) \\
\hline
\end{tabular}

\footnotetext{
${ }^{i}$ These estimates are the authors own calculations from the confidentialised unit record files of 2009-2010 Australia Bureau of Statistics Survey of Income and Housing.

ii The typical project model approach to analysis of rental investment decisions is based on a present value model that is solved for the investor's user cost of capital and then used to measure the impacts of changes in critical financial parameters. See for example, De Leeuw and Ozanne (1981); Fisher and Lentz (1986); Follain et al. (1987); Hendershott and Ling (1984); and MacNevin (1997).

iii Other financial assets can be structured to yield a regular stream of income but there can be an opportunity cost. For example, rather than 'store' all savings in one term deposit, the investor can spread their savings across term deposits with different maturities; but spreading savings across term deposits is likely to lower the average interest yield because financial institutions tend to offer higher interest rates on larger deposits
} 
iv The sample is limited to the rental property holdings of households and excludes the holdings of companies and financial institutions. Most rental properties are owned by households in part because tax arrangements deter investment from companies and financial institutions.

${ }^{\mathrm{v}} 90 \%$ of these landlords had only one spell as a rental investor over the timeframe 2001-2006. $49 \%$ of all spells were ongoing in 2001, the remaining 51\% starting between 2002 and 2006.

${ }^{\text {vi }}$ Financial instruments include shares, cash investments, bank accounts, trust funds and redeemable life insurance.

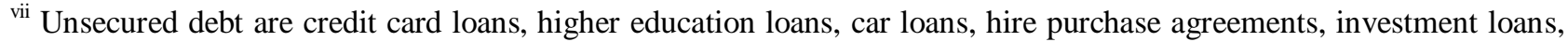
personal loans from a bank/financial institution, loans from other lenders, loans from friends/relatives and overdue personal bills.

viii 741 landlords had spells beginning after 2002, or ending by 2002 that are not therefore included in this sample. There are also landlords in 2002 with missing data on key asset and debt variables, or who were not re-interviewed in 2006. The unavailability of wealth modules in each wave means that we are unable to fully exploit the longitudinal nature of the data by (for example) estimating a proportional hazards model.

${ }^{\text {ix }}$ An income unit is defined as a person or group of persons related by marriage or parent-child relationships who live within the same household and share income (Australian Bureau of Statistics, 1997). Over 80\% of households comprise only one income unit.

${ }^{x}$ See Wood and Ong (2009, p57-58) for a formal algebraic statement of the user cost expression. For a comparison of user cost under alternative taxation regimes (Australia and the UK) see Wood and Kemp (2003).

${ }^{x i}$ We are grateful to an anonymous referee for suggesting this line of enquiry.

${ }^{x i i}$ With the exception of gross rental yield (unobservable for non-investors) all variables in the survival model are included in the first stage probit landlord status model. Non-property wealth and income are added as new variables. Estimates are available from the authors on request. 